\title{
$\beta$-Adrenergic Receptors Link NO/sGC/PKG Signaling to BDNF Expression During the Consolidation of Object Recognition Long-Term Memory
}

\author{
Cristiane R. Furini, Janine I. Rossato, Lucas L. Bitencourt, Jorge H. Medina, \\ Iván Izquierdo, and Martín Cammarota*
}

\begin{abstract}
The nitric oxide (NO)/soluble guanylyl cyclase (sGC)/ protein kinase G (PKG) pathway is important for memory processing, but the identity of its downstream effectors as well as its actual participation in the consolidation of nonaversive declarative long-term memory (LTM) remain unknown. Here, we show that training rats in an object recognition (OR) learning task rapidly increased nitrites/nitrates (NOx) content in the CA1 region of the dorsal hippocampus while posttraining intra-CA1 microinfusion of the neuronal NO synthase (nNOS) inhibitor L-NN hindered OR LTM retention without affecting memory retrieval or other behavioral variables. The amnesic effect of L-NN was not state dependent, was mimicked by the sGC inhibitor LY83583 and the PKG inhibitor KT-5823, and reversed by coinfusion of the NO donor $S$-nitroso- $N$-acetylpenicillamine (SNAP) and the PKG activator 8-bromoguanosine $3^{\prime}, 5^{\prime}$-cyclic monophosphate (8Br-cGMP). SNAP did not affect the amnesic effect of LY83583 and KT-5823. Conversely, 8Br-cGMP overturned the amnesia induced by LY83583 but not that caused by $\mathrm{KT}-5823$. Intra-CA1 infusion of the $\beta$-adrenergic receptor blocker timolol right after training hindered OR LTM and, although coadministration of noradrenaline reversed the amnesia caused by L-NN, LY83583, and KT5823, the amnesic effect of timolol was unaffected by coinfusion of $8 \mathrm{Br}$-cGMP or SNAP, indicating that hippocampal $\beta$-adrenergic receptors act downstream NO/sGC/PKG signaling. We also found that posttraining intra-CA1 infusion of function-blocking anti-brain-derived neurotrophic factor (BDNF) antibodies hampered OR LTM retention, whereas OR training increased CA1 BDNF levels in a nNOS- and $\beta$-adrenergic receptor-dependent manner. Taken together, our results demonstrate that NO/sGC/PKG signaling in the hippocampus is essential for OR memory consolidation and suggest that $\beta$-adrenergic receptors link the activation of this pathway to BDNF expression during the consolidation of declarative memories. $\odot 2009$ Wiley-Liss, Inc.
\end{abstract}

KEY WORDS: memory; hippocampus; noradrenaline; nitric oxide; BDNF; consolidation; object recognition

Centro de Memória, Instituto do Cérebro, Pontifícia Universidade Católica do Rio Grande do Sul and Instituto Nacional de Neurociência Translacional, Conselho Nacional de Desenvolvimento Científico e Tecnológico, Brasil

Grant sponsor: Conselho Nacional de Desenvolvimento Cientifico e Tecnológico (CNPq); Grant sponsor: Coordenação de Aperfeiçoamento de Pessoal de Nível Superior (CAPES), Brazil.

*Correspondence to: Martín Cammarota, Centro de Memória, Instituto do Cérebro and Instituto Nacional de Neurociência Translacional, Pontifícia Universidade Católica de Rio Grande do Sul (PUCRS), Av. Ipiranga 6690, Andar 2, Porto Alegre, RS 90610-000, Brasil. E-mail: mcammaro@ terra.com.br or martin.cammarota@pucrs.br

Accepted for publication 28 April 2009

DOI 10.1002/hipo.20656

Published online 16 June 2009 in Wiley InterScience (www.interscience. wiley.com).

\section{INTRODUCTION}

As far as long-term memory (LTM) is concerned, there is evidence for different kinds of representations. In this context, declarative, or explicit, memory is defined as the memory for facts and events and is often divided into episodic (memory for events within one's own life) and semantic memory (general knowledge about aspects of the world). Information about sensorial, spatial, and contextual attributes of previously encountered objects are important elements of most declarative memories. Indeed, difficulty to recognize familiar items or to discriminate them from novel ones is one of the early symptoms of cognitive decline in Alzheimer's disease (AD; Laatu et al., 2003; Lee et al., 2003; Dudas et al., 2005; Budson et al., 2005). For these and other reasons, learning paradigms based upon object recognition (OR) are key to understand the neurobiology of declarative memory (Winters et al., 2008).

Functional integrity of the medial temporal lobe, including the hippocampus, the amygdala and the entorhinal, perirhinal, and parahippocampal cortices, is essential for OR memory processing (Ennaceur and Delacour, 1988; Logothetis and Sheinberg, 1996; Clark et al., 2000; Riesenhuber and Poggio, 2002). In particular, lesion and pharmacological studies suggest that the hippocampal formation is required for acquisition and storage of information regarding contextual details and the temporal order of previous experiences (Balderas et al., 2008). However, very little is known at the molecular level about the mechanisms contributing to OR LTM consolidation in the hippocampus.

Nitric oxide (NO) is a highly diffusible gas synthesized from L-arginine by a group of enzymes known as NO synthases [NOS1-3; also referred to as neuronal NOS, or nNOS, endothelial NOS, or eNOS, and inducible NOS, or iNOS, respectively]. In the central nervous system $\mathrm{NO}$ acts as a retrograde messenger to regulate neurotransmitter and neuropeptide release in an activity-dependent manner (Hanbauer et al., 1992; Son et al., 1996). NO signaling is mostly mediated by soluble guanylyl cyclase (sGC) (Arnold et al., 1977), leading to the activation of cGMP-dependent protein kinase (PKG). PKG, in turn, enhances neurotransmit- 
ter release (Hawkins et al., 1993; 1998) and regulates gene transcription (Lu et al., 1999; Wang et al., 1999). The NO/ sGC/PKG pathway plays a key role in synaptic plasticity. It is known that long-term potentiation (LTP) and depression (LTD) in different regions of the brain require sGC and PKG activity (Boulton et al., 1995; Chien et al., 2003; Shin and Linden, 2005; Zhang et al., 2006; Haghikia et al., 2007) and behavioral and pharmacological studies suggest a causal link between NO and PKG in memory (Edwards and Rickard, 2007). Thus, peripheral administration of NOS inhibitors impairs (Prickaerts et al., 1997) while NO donors enhance (Pitsikas et al., 2002) retention of OR short-term memory (STM). Indeed, abundant evidence indicates that NOS contributes to the pathogenesis of AD (Chabrier et al., 1999; Lahiri et al., 2003; Rodrigo et al., 2004; Lüth et al., 2005; Malinski, 2007; Stepanichev et al., 2008). Degeneration of the locus coeruleus (LC), the main source of noradrenergic inputs to the hippocampus, is one of the early features of AD (Haglund et al., 2006; Weinshenker, 2008). Although the functional consequences of noradrenaline (NA) depletion for the progression of $\mathrm{AD}$ are not clear, evidence indicates that administration of $\beta$-adrenergic receptors blockers exacerbates declarative memory deficits in cognitively impaired patients (Gliebus and Lippa, 2007), suggesting that NA signaling is important for explicit memory processing. In fact, noradrenergic activation of the basolateral amygdala modulates consolidation of OR memory (Roozendaal et al., 2008). Because NO regulates NA release in the hippocampus (Lonart et al., 1992; Lonart and Johnson, 1995; Satoh et al., 1996), novelty detection increases hippocampal NA release (Ihalainen et al., 1999), and this catecholamine modulates the expression of proteins relevant for memory (Kobayashi and Yasoshima, 2001), including BDNF (Hutter et al., 1996; Haenisch et al., 2008), we examined the contribution of the NOS/sGC/PKG cascade in the hippocampus to the consolidation of OR LTM and analyzed the possible functional link between nNOS activation, NA signaling, and BDNF expression during this process.

\section{MATERIALS AND METHODS}

\section{Surgery and Drug Infusion Procedures}

Naive male Wistar rats (3-month-old 250-280 g) raised in our own facilities or bought at FEPPS (Fundação Estadual de Produção e Pesquisa em Saúde do Rio Grande do Sul, Porto Alegre, Brazil) were used. The animals were housed five to a cage and kept with freely access to food and water under a 12$\mathrm{h}$ light-dark cycle, with light onset at 7:00 AM. The temperature of the animal's room was maintained at $22-24^{\circ} \mathrm{C}$. To implant them with indwelling cannulas, rats were deeply anesthetized with thiopental (i.p., $30-50 \mathrm{mg} / \mathrm{kg}$ ) and 27 -gauge cannulas stereotaxically aimed to the CA1 region of the dorsal hippocampus, in accordance with coordinates (A $-4.2 \mathrm{~L} \pm 3.0$, $\mathrm{V}$ 1.8) taken from the atlas of Paxinos and Watson (1986). Animals were allowed to recover from surgery for 4 days before submitting them to any other procedure. At the time of drug delivery, 30-gauge infusion cannulas were tightly fitted into the guides. Infusions $(1 \mu \mathrm{l} / \mathrm{side})$ were carried out over $60 \mathrm{~s}$ with an infusion pump, and the cannulas were left in place for 60 additional seconds to minimize backflow. The placement of the cannulas was verified postmortem: $2-4 \mathrm{~h}$ after the last behavioral test, $1 \mu \mathrm{l}$ of a $4 \%$ methylene-blue solution was infused as described earlier, and the extension of the dye $30 \mathrm{~min}$ thereafter was taken as an indication of the presumable diffusion of the vehicle or drug previously given to each animal. Only data from animals with correct implants were analyzed. All procedures were conducted in accordance with the "Principles of laboratory animal care" (NIH publication No. 85-23, revised 1996). Every effort was made to reduce the number of animals used and to minimize their suffering.

\section{OR Paradigm}

Training and testing in the object recognition (OR) task was carried out in an open-field arena $(50 \times 50 \times 50 \mathrm{~cm})$ built of polyvinyl chloride plastic, plywood and transparent acrylic as described (Myskiw et al., 2008; Rossato et al., 2007). Before training, animals were habituated to the experimental arena by allowing them to freely explore it during $20 \mathrm{~min}$ per day for 4 days in the absence of any behaviorally relevant stimulus. The stimulus objects were made of metal, glass, or glazed ceramic. There were several copies of each object, which were used interchangeably. Glued to the base of each object was a piece of Velcro, which was used to fix the object to the floor. The role (familiar or novel) and the relative position of the two stimulus objects were counterbalanced and randomly permuted for each experimental animal. The open field arena and the stimulus objects were cleaned thoroughly between trials to ensure the absence of olfactory cues. Exploration was defined as sniffing or touching the objects with the nose and/or forepaws. Sitting on or turning around the objects was not considered exploratory behavior. A video camera was positioned over the arena, and the rats' behavior was recorded using a video tracking and analysis system for later evaluation. The experiments were performed by an observer blind to the treatment condition of the animals.

For training, rats were placed in the open field containing two different objects and left to freely explore them for $5 \mathrm{~min}$. The test session was performed $24 \mathrm{~h}$ after training. In the test session, one of the familiar objects was randomly replaced by a novel one, and rats were reintroduced into the open field for five additional minutes. The compounds to be tested were bilaterally infused into the CA1 region of the dorsal hippocampus $(1 \mu \mathrm{l} / \mathrm{side})$ at different times after training. Data were analyzed using one-sample Student's $t$-test. 


\section{One Trial Step-Down Inhibitory Avoidance}

Rats were trained in a one-trial, step-down inhibitory avoidance task as previously described (Bevilaqua et al., 2005). Briefly, the training apparatus was a $50 \times 25 \times 25 \mathrm{~cm}$ plexiglass box with a $5 \mathrm{~cm}$-high, $8 \mathrm{~cm}$-wide, and $25-\mathrm{cm}$ long platform on the left end of a series of bronze bars which made up the floor of the box. For training, animals were gently placed on the platform facing the left rear corner of the training box. When they stepped down and placed their four paws on the grid, received a $2 \mathrm{~s}, 0.8 \mathrm{~mA}$ scrambled footshock. Memory retention was evaluated in a nonreinforced test session carried out at $24 \mathrm{~h}$ after training. Data were analyzed using ANOVA.

\section{Open Field and Plus Maze}

To analyze their exploratory and locomotor activities, the animals were placed on the left rear quadrant of a $50 \times 50 \times$ $39-\mathrm{cm}$ open field with black plywood walls and a brown floor divided into 12 equal imaginary squares. The number of line crossings and the number of rearings were measured over 5 min and taken as an indicator of locomotor and exploratory activities, respectively. To evaluate their anxiety state, rats were exposed to an elevated plus maze as detailed in Pellow et al. (1985). The total number of entries into the four arms, the number of entries, and the time spent into the open arms were recorded over a 5 min session. Data were analyzed using oneway ANOVA.

\section{Immunoblot Assays}

Animals we killed by decapitation and the CA1 region of the dorsal hippocampus rapidly dissected out and homogenized in ice-chilled buffer $(20 \mathrm{mM}$ Tris-HCL, $\mathrm{pH} 7.4,0.32 \mathrm{M}$ sucrose, $1 \mathrm{mM}$ EDTA, $1 \mathrm{mM}$ EGTA, $1 \mathrm{mM}$ PMSF, $10 \mu \mathrm{g} / \mathrm{ml}$ aprotinin, $15 \mu \mathrm{g} / \mathrm{ml}$ leupeptin, $10 \mu \mathrm{g} / \mathrm{ml}$ bacitracin, $10 \mu \mathrm{g} / \mathrm{ml}$ pepstatin, $15 \mu \mathrm{g} / \mathrm{ml}$ trypsin inhibitor, $50 \mathrm{mM} \mathrm{NaF}$, and $1 \mathrm{mM}$ sodium orthovanadate). Protein concentration was determined using the BCA protein assay (Pierce, Rockford, IL), and equal amounts of protein were fractionated by SDS-PAGE before being electrotransferred to polyvinylidene difluoride membranes (PVDF; Immobilon-P, Millipore, MS). After verification of protein loading by Ponceau $S$ staining, the blots were blocked in Tween-Tris buffer saline (TTBS; $100 \mathrm{~mm}$ Tris- $\mathrm{HCl}, \mathrm{pH}$ 7.5, containing $0.9 \% \mathrm{NaCl}$ and $0.1 \%$ Tween 20 ) and incubated overnight with anti-BDNF antibody (N20, 1:5,000, Santa Cruz Biotechnology, Santa Cruz, CA). The membranes were washed in TTBS and incubated with HRP-coupled anti$\operatorname{IgG}$ antibody, washed again, and the immunoreactivity detected using the West-Pico enhanced chemiluminescence kit (Pierce, IL). Densitometric analysis was carried out in an ImageQuant RT-ECL system (GE, Piscataway, NJ).

\section{Determination of Nitrites/Nitrates Content}

Nitrites/nitrates (NOx) content was determined as described by Tracey et al. (1995) and Grandati et al. (1997). Briefly, the
CA1 region of the dorsal hippocampus was dissected out, weighed, homogenized in deionized water, and centrifuged at $20,000 \mathrm{~g}$ for $10 \mathrm{~min}$. Aliquots of the supernatants were combined with a reaction mix containing $0.31 \mathrm{M}$ potassium phosphate buffer ( $\mathrm{pH}$ 7.5), $0.86 \mathrm{mM} \beta-\mathrm{NADPH}, 0.11 \mathrm{mM}$ FAD, and $20 \mathrm{mu}$ of nitrate reductase. Samples were allowed to incubate for $1 \mathrm{~h}$ at room temperature in the dark, and the reaction was halted by adding $1 \mathrm{M} \mathrm{ZnSO} 4$. Samples were centrifuged at $20,000 \mathrm{~g}$ for $5 \mathrm{~min}$, and the supernatants were removed. One hundred microliters of Griess reagent (1:1 mixture of $1 \%$ sulfani-lamide in $5 \% \mathrm{H} 3 \mathrm{PO} 4$ and $0.1 \% N$-(1-naphytyl)ethylenedia-mine) were added to the supernatants and the mixture
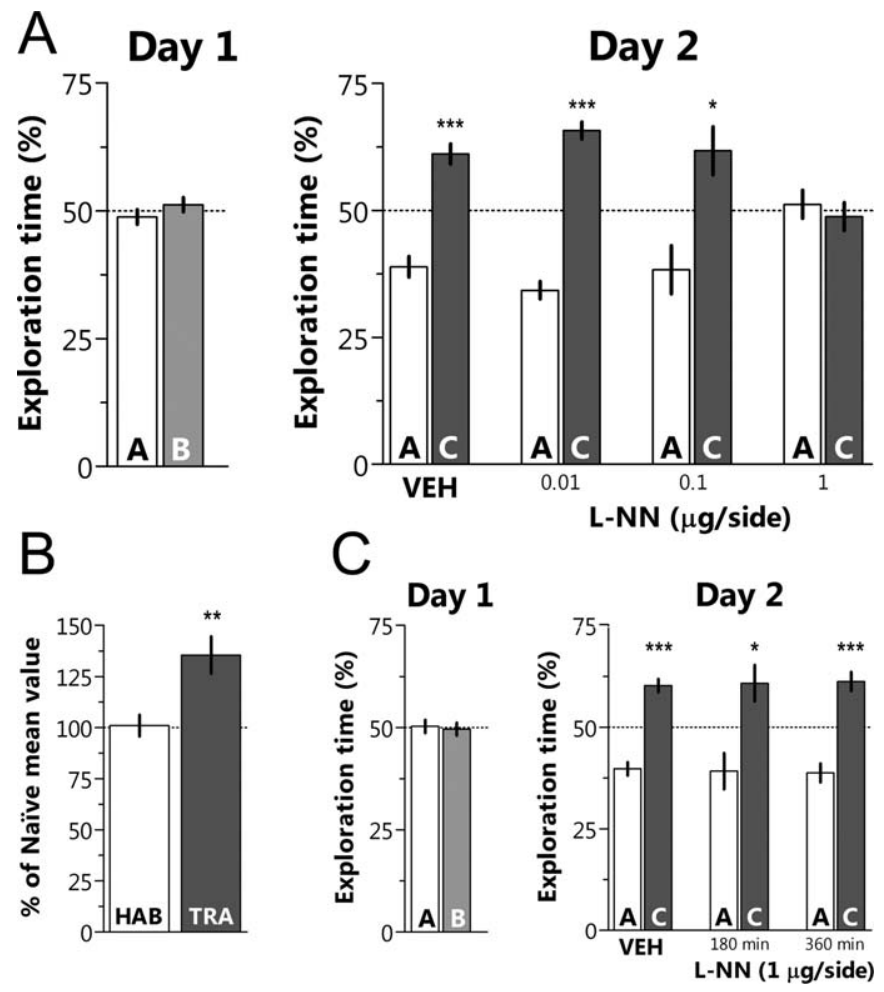

FIGURE 1. Posttraining inhibition of nNOS impairs retention of object recognition long-term memory. A: On day 1 (training), rats were exposed to two different objects (A and B) for $5 \mathrm{~min}$ and immediately after that received bilateral infusions $(1 \mu \mathrm{l} / \mathrm{side})$ of vehicle (VEH; $0.1 \%$ DMSO in saline) or L-NN (0.01-1 $\mu \mathrm{g} / \mathrm{side})$ in the CA1 region of the dorsal hippocampus. On day 2 (test), animals were exposed to a familiar (A) and a novel object (C) for five extra minutes to evaluate long-term memory retention. Data (mean \pm SEM) are presented as percentage of total exploration time. ${ }^{* * *} P<0.001,{ }^{* *} P<0.01$, and ${ }^{*} P<0.05$ in one-sample Student's $t$-test with theoretical mean $=50 ; n=10$ per group. $B$ : Animals were trained in the OR task (TRA) or submitted to a 5min long free exploration session of the training arena in the absence of stimulus objects (HAB). The animals were killed immediately after the behavioral procedures and the dorsal CA1 region dissected out and processed to evaluate nitrite/nitrate content as described in Materials and Methods section. Data are expressed as percentage of Naive control values. ${ }^{* *} P<0.01$ in two-tailed Student's $t$-test; $n=9$ per group. C: Animals were trained and treated as in (A) except that L-NN (1 $\mu \mathrm{g} / \mathrm{side})$ was infused $180 \mathrm{~min}$ or 360 min posttraining. ${ }^{* * *} P<\mathbf{0 . 0 0 1}$ and ${ }^{*} P<0.05$ in one-sample Student's $t$-test with theoretical mean $=50 ; n=10$ per group. 
TABLE 1

Intra-CA1 Administration of L-NN Does Not Affect Exploration in the OR Paradigm

total exploration time $(S)$

Training session

$49.5 \pm 3.3$

Test session

VEH

L-NN $(0.01 \mu \mathrm{g} /$ side $)$

L-NN $(0.1 \mu \mathrm{g} /$ side $)$

L-NN $(1 \mu \mathrm{g} /$ side $)$

$50.9 \pm 4.2$

$48.3 \pm 3.9$

$46.2 \pm 4.3$

$51.1 \pm 5.7$

Total exploration time $(S$; mean \pm SEM) during training and test sessions for the animals presented in Figure $1 \mathrm{~A}$.

incubated for $15 \mathrm{~min}$ at room temperature. Absorbance was measured at $540 \mathrm{~nm}$ and converted to $\mathrm{NO}$ content by using a nitrate standard curve.

\section{Reagents}

$N_{\omega}$-Nitroarginine-2,4-L-diaminobutyric amide di(trifluoroacetate) (L-NN), KT-5,823, 8-bromoguanosine $3^{\prime}, 5^{\prime}$-cyclic monophosphate (8Br-cGMP), timolol, and NA were from Sigma-Aldrich (St Louis, MO). Brain-derived neurotrophic factor (BDNF) was from Alomone Labs (Jerusalem, Israel). AntiBDNF and function blocking anti-BDNF antibody were from Sigma-Aldrich or from Santa Cruz Biotechnology (Santa Cruz, CA). 6-Anilino-5,8-quinolinedione (LY83583) and S-nitrosoacetylpenicillamine (SNAP) were from Calbiochem (La Jolla, CA). SNAP was prepared right before use. All other drugs were dissolved in saline or DMSO and stored protected from light at $-20^{\circ} \mathrm{C}$ until use. Right before that an aliquot was thawed and diluted to working concentration with $0.1 \%$ DMSO in saline $(\mathrm{pH}$ 7.2). The doses used were determined based on pilot experiments and on previous studies showing the effect of each compound on learning or behavioral performance (Jouvert et al., 2004; Watts et al., 2005; Bekinschtein et al., 2008; Cammarota et al., 2008; Ota et al., 2008; Romieu et al., 2008).

\section{RESULTS}

To analyze the effect of nNOS inhibition on OR LTM, male Wistar rats were trained in an OR learning task involving exposure to two different novel stimuli objects. Immediately after training, the animals received bilateral intra-CA1 infusions of vehicle (VEH; 0.1\% DMSO in saline) or of the nNOS inhibitor $N_{\omega}$-nitroarginine-2,4-L-diaminobutyric amide di(trifluoroacetate, L-NN; 0.01-1 $\mu \mathrm{g} / \mathrm{side})$. LTM was evaluated $24 \mathrm{~h}$ later. In the LTM retention test session, the animals were exposed for 5 min to one of the objects presented during training together with a novel one. Rats that received VEH or low doses of L-NN (0.01 and $0.1 \mu \mathrm{g} / \mathrm{side})$ explored the novel object significantly longer than the familiar one (Fig. $1 \mathrm{~A} ; t_{(9)}=5.49, P$ $<0.001$ for $\mathrm{VEH} ; t_{(9)}=9.27, P<0.001$ for $0.01 \mu \mathrm{g} / \mathrm{side}$ and $t_{(9)}=2.47, P<0.05$ for $0.1 \mu \mathrm{g} /$ side L-NN in one-sample Student's $t$-test with theoretical mean $=50$ ). On the contrary, animals that received $1 \mu \mathrm{g} / \mathrm{side} \mathrm{L}-\mathrm{NN}$ spent the same amount of time exploring the novel and the familiar object (Fig. 1A), suggesting that nNOS is necessary early after training for retention of OR LTM. In agreement with this assertion, OR training increased NOx content in dorsal CA1 immediately posttraining (Fig. $1 \mathrm{~B} ; t_{(18)}=3.27, P<0.01$ in two-tailed Student's $t$-test). No significant effect of L-NN on OR memory was observed when it was given 180 - or 360-min posttraining (Fig. $1 \mathrm{C} ; t_{(9)}=2.43, P<0.05$ for $180 \mathrm{~min} ; t_{(9)}=4.85, P<$ 0.001 for $360 \mathrm{~min}$ in one-sample Student's $t$-test with

TABLE 2 .

Bilateral Intra-CA1 Infusions of L-NN, LY83583, and KT5823 in the CA1 Region of the Dorsal Hippocampus Have No Effect on Locomotor and Exploratory Activities, Anxiety, or Hippocampal Function

\begin{tabular}{|c|c|c|c|c|}
\hline & VEH & L-NN & LY83583 & KT5823 \\
\hline \multicolumn{5}{|l|}{ Plus maze } \\
\hline Total entries & $15.5 \pm 1.3$ & $14.5 \pm 1.8$ & $16.2 \pm 1.9$ & $13.4 \pm 3.1$ \\
\hline$\%$ Time in the open arms & $40.2 \pm 3.1$ & $37.6 \pm 4.8$ & $41.6 \pm 4.1$ & $35.7 \pm 2.6$ \\
\hline \multicolumn{5}{|l|}{ Open field } \\
\hline Crossings & $35.9 \pm 5.2$ & $39.0 \pm 5.5$ & $38.2 \pm 4.5$ & $40.3 \pm 4.8$ \\
\hline Rearings & $12.2 \pm 2.5$ & $12.8 \pm 2.1$ & $11.2 \pm 1.1$ & $13.4 \pm 2.5$ \\
\hline \multicolumn{5}{|l|}{ Inhibitory avoidance } \\
\hline Training step-down latency $(S)$ & $10.2 \pm 1.9$ & $11.5 \pm 3.1$ & $12.0 \pm 1.8$ & $14.5 \pm 1.4$ \\
\hline Test step-down latency $(S)$ & $201.1 \pm 30.5$ & $228.7 \pm 28.9$ & $227.1 \pm 19.6$ & $213.6 \pm 23.2$ \\
\hline
\end{tabular}

L-NN (1 $\mu \mathrm{g} / \mathrm{side})$, LY83583 (200 ng/side), or KT5823 (200 ng/side) were infused into the CA1 region of the dorsal hippocampus $24 \mathrm{~h}$ before an open field, a plus maze or a training session in step down inhibitory avoidance. Data are expressed as mean ( \pm SEM) of the total number of entries and the percentage of time spent in the open arms (plus maze; $n=8$ per group), the number of crossings and rearings (open field; $n=8$ per group) and training/test step-down latency ( $S$ ). $\mathrm{VEH}=$ vehicle. A different set of animals was used for each behavioral test. 


\section{L-NN/VEH}

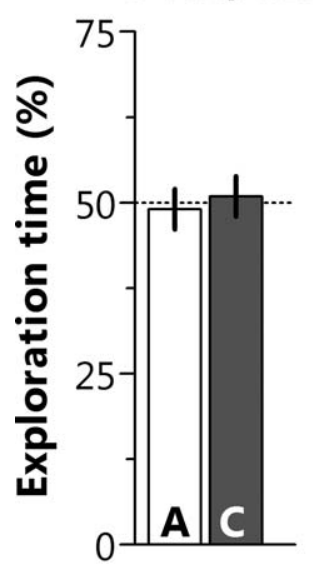

VEH/VEH

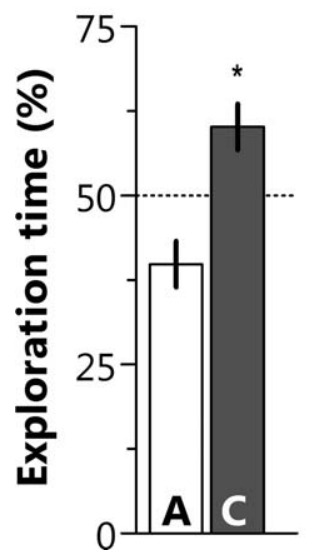

L-NN/L-NN

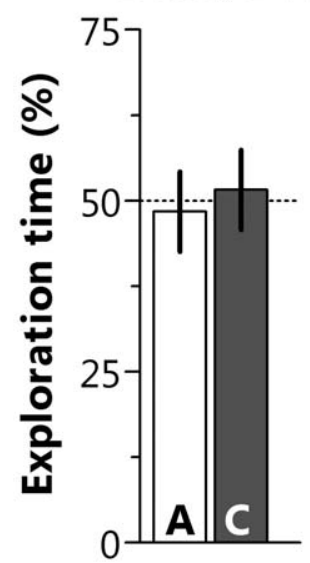

\section{VEH/L-NN}

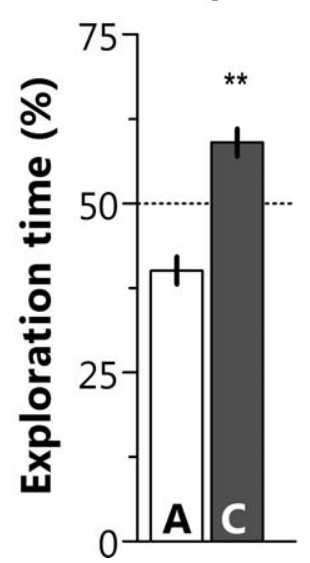

FIGURE 2. The amnesic effect of L-NN is not due to state-dependency. Rats were exposed to two different objects for $5 \mathrm{~min}$ and immediately after that received bilateral infusions $(1 \mu \mathrm{l} /$ side $)$ of vehicle (VEH; $0.1 \%$ DMSO in saline) or $\mathrm{L}-\mathrm{NN}(1 \mu \mathrm{g} / \mathrm{side})$ in the CA1 region of the dorsal hippocampus. After that the animals were divided in four different groups. Two of the groups (VEH/ VEH and L-NN/VEH) received bilateral intra-CA1 infusions of VEH and the other two (VEH/L-NN and L-NN/L-NN) received intra-CA1 L-NN (1 $\mu \mathrm{g} / \mathrm{side}) 15 \mathrm{~min}$ before being exposed to a familiar (A) and a novel object $(C)$ for five extra minutes to evaluate LTM retention. Data (mean \pm SEM) are presented as percentage of total exploration time during the retention test session. ${ }^{* *} P<$ 0.01 and $* P<0.05$ in one-sample Student's $t$-test with theoretical mean $=50 ; n=10$ per group.

theoretical mean $=50$ ). Importantly, L-NN did not affect total exploration time during the $\mathrm{OR}$ retention test session (Table 1).

To investigate whether the amnesia caused by L-NN was actually due to impairment of the consolidation process or instead it was induced by a delayed action on hippocampal function, anxiety and/or exploratory activity able to hinder retrieval of OR LTM, rats received bilateral intra-CA1 infusions of L-NN ( $1 \mu \mathrm{g} /$ side) $24 \mathrm{~h}$ before exposure to a plus maze or an open field arena. L-NN had no effect in the total number of entries or in the percentage of time spent in the open arms

during the plus maze session (Table 2; plus maze). Similarly, L-NN did not affect the number of crossings and rearings during a 5-min long free-exploration session of the open field arena (Table 2; open field). Moreover, when given into dorsal CA1 $24 \mathrm{~h}$ before training, L-NN did not affect acquisition or retention of inhibitory avoidance LTM (Table 2; inhibitory avoidance), a learning task that requires the functional integrity of the hippocampal formation (Izquierdo et al., 2006).

The amnesia induced by nNOS inhibition was not due to state-dependency. Intra-CA1 infusion of L-NN (1 $\mu \mathrm{g} /$ side) immediately after training led to poor OR LTM retention in rats given either VEH or L-NN 15 min before a test session $24 \mathrm{~h}$ after training (Fig. 2; L-NN/VEH and L-NN/L-NN groups, respectively; $\left(t_{(9)}=0.31, P=0.76\right.$ for $\mathrm{L}-\mathrm{NN} / \mathrm{VEH} ; t_{(9)}=$ $0.27, P=0.79$ for L-NN/L-NN in one-sample Student's $t$-test with theoretical mean $=50$ ). Also note that when L-NN was given $15 \mathrm{~min}$ before the test session to rats that had received VEH immediately after training, it had no effect on OR LTM expression (Fig. 2, VEH/L-NN group; $t_{(9)}=4.49, P<0.01$ in one-sample Student's $t$-test with theoretical mean $=50$ ).

Because the sGC/cGMP/PKG pathway mediates most of the physiological responses to $\mathrm{NO}$ in different experimental preparations (Bouallegue et al., 2007; Haghikia et al., 2007; PrietoCastelló et al., 2007; Spolidório et al., 2007), we studied the participation of this signaling cascade in OR LTM. Intra-CA1 infusion of the sGC inhibitor 6-anilino-5,8-quinolinedione (LY83583, 2-200 ng/side; Fig. 3A) or of the PKG inhibitor KT5823 (1-100 ng/side, Fig. 3B) immediately after training blocked OR memory retention $24 \mathrm{~h}$ later $\left(t_{(9)}=3.84, P<\right.$ 0.01 for $2 \mathrm{ng} / \mathrm{side} \mathrm{LY} 83583$; $t_{(9)}=3.06, P<0.05$ for $20 \mathrm{ng} /$ side LY83583; $t_{(9)}=0.07, P=0.94$ for $200 \mathrm{ng} / \mathrm{side}$ LY83583; $t_{(9)}=10.28, P<0.001$ for $1 \mathrm{ng} /$ side KT5823; $t_{(9)}$ $=2.69, P<0.01$ for $10 \mathrm{ng} / \mathrm{side} \mathrm{KT} 5823$ and $t_{(9)}=0.23$, $P=0.82$ for $100 \mathrm{ng} /$ side KT5823 in one-sample Student's $t$ test with theoretical mean $=50$ ). LY83583 and KT5823 did not affect OR LTM when given into CA1 180 or 360min posttraining (not shown). Coinfusion of the NO donor $S$-nitroso- $N$-acetylpenicillamine (SNAP; $5 \mu \mathrm{g} /$ side) did not affect the amnesia induced by LY83583 and KT5823 but reversed that caused by L-NN (Fig. $3 \mathrm{C} ; t_{(9)}=0.76, P=0.47$ for LY83583/SNAP; $t_{(9)}=0.42, P=0.68$ for KT5823/ KT5823 and $t_{(9)}=8.35, P<0.001$ for L-NN/SNAP in onesample Student's $t$-test with theoretical mean $=50$ ). Conversely, coinfusion of the nonhydrolysable analog of cGMP, 8Br-cGMP (5 $\mu \mathrm{g} /$ side) reversed the amnesic effect of L-NN and LY83583 but not that induced by KT5823 (Fig. 3D; $t_{(9)}$ 4.32, $P<0.01$ for L-NN/8Br-cGMP; $t_{(9)}=2.63, P<$ 0.05 for LY83583/8Br-cGMP and $t_{(9)}=0.86, P=0.41$ for KT5823/8Br-cGMP in one-sample Student's $t$-test with theoretical mean $=50)$. LY83583 and KT5823 did not affect acquisition of IA LTM when given into dorsal CA1 $24 \mathrm{~h}$ before training. None of these two drugs modified the number of crossings and rearings in an open field or changed the number of entries and the time spent in the open arms of an elevated plus maze when infused into dorsal CA1 $24 \mathrm{~h}$ before the respective behavioral session (Table 2). 
A Day 1
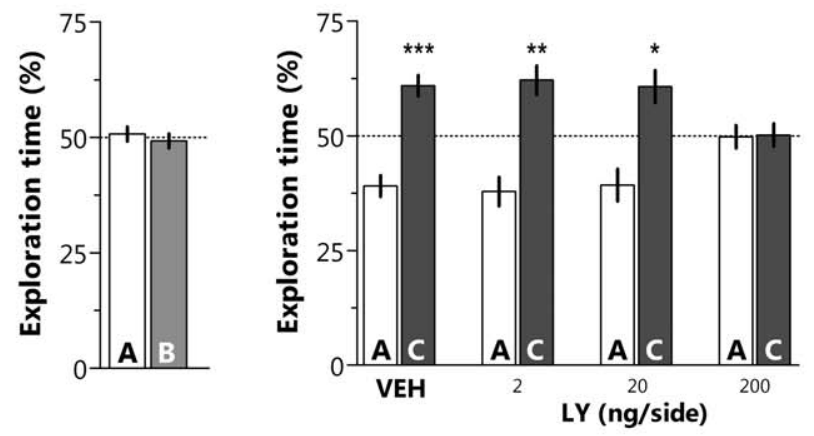

C
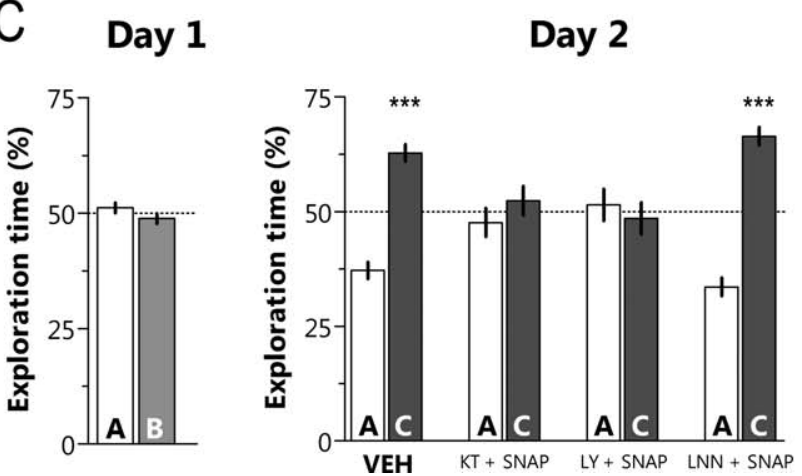

FIGURE 3. Posttraining inhibition of $s G C$ and PKG in the CA1 region of the dorsal hippocampus hinders consolidation of object recognition long-term memory. Effects of SNAP and 8Br-cGMP. On day 1 (training), rats were exposed to two different objects (A and B) for $5 \mathrm{~min}$ and immediately after that received bilateral intra-CA1 infusions ( $1 \mu \mathrm{l} /$ side) of vehicle (VEH; $0.1 \%$ DMSO in saline), (A) the sGC inhibitor LY83583 (LY; 2, 20, or $200 \mathrm{ng} / \mathrm{side}$ ), (B) the PKG inhibitor KT5823 (KT; 1, 10, or $100 \mathrm{ng} / \mathrm{side})$, (C) a combination of LY (200 ng/side) plus SNAP
B Day 1

Day 2
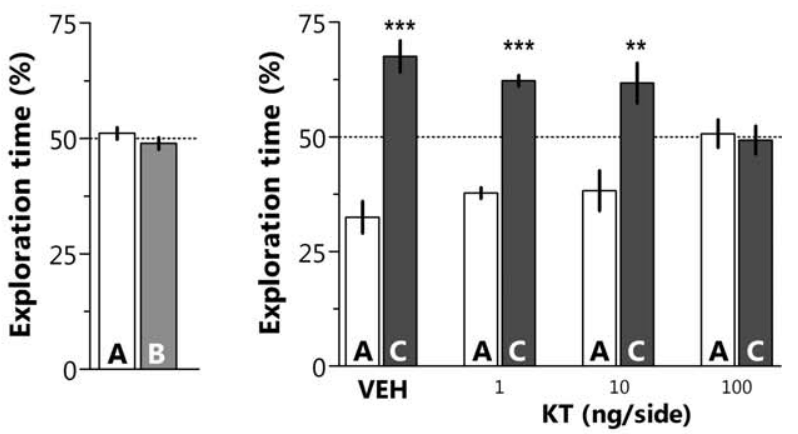

D Day 1
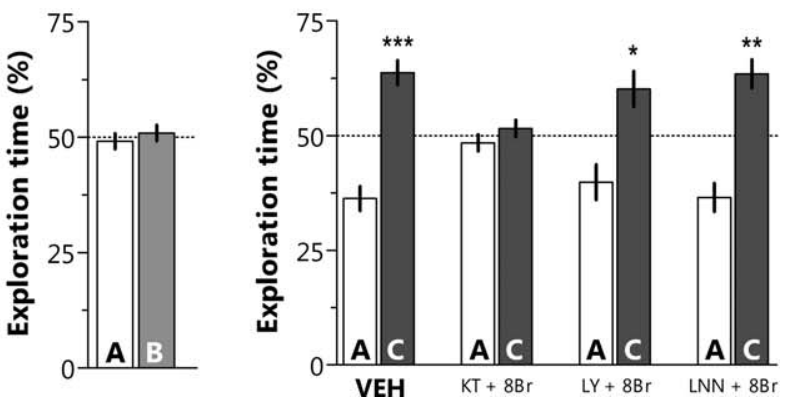

( $5 \mu \mathrm{g} / \mathrm{side})$, KT (100 ng/side) plus SNAP or L-NN ( $1 \mu \mathrm{g} / \mathrm{side}) \mathrm{plus}$ SNAP, or (D) a combination of LY (200 ng/side) plus $8 \mathrm{Br}$-cGMP (8Br; $5 \mu \mathrm{g} /$ side), KT (100 ng/side) plus $8 \mathrm{Br}$, or L-NN (1 $\mu \mathrm{g} / \mathrm{side})$ plus $8 \mathrm{Br}$. On day 2 (test), animals were exposed to a familiar (A) and a novel object (C) for five extra minutes to evaluate long-term memory retention. Data (mean \pm SEM) are presented as percentage of total exploration time. ${ }^{* * *} P<\mathbf{0 . 0 0 1},{ }^{* *} P<0.01$, and ${ }^{*} P<0.05$ in one-sample Student's $t$-test with theoretical mean $=50 ; n=10$ per group.
Day 1

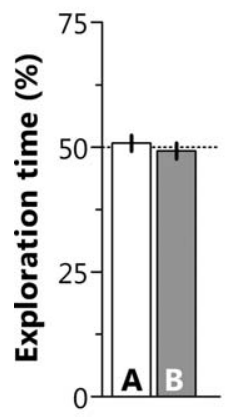

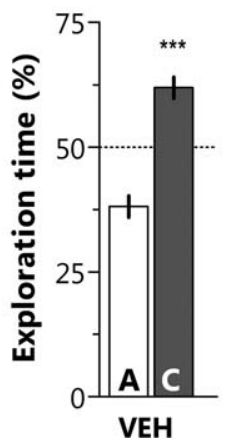

VEH
Day 2
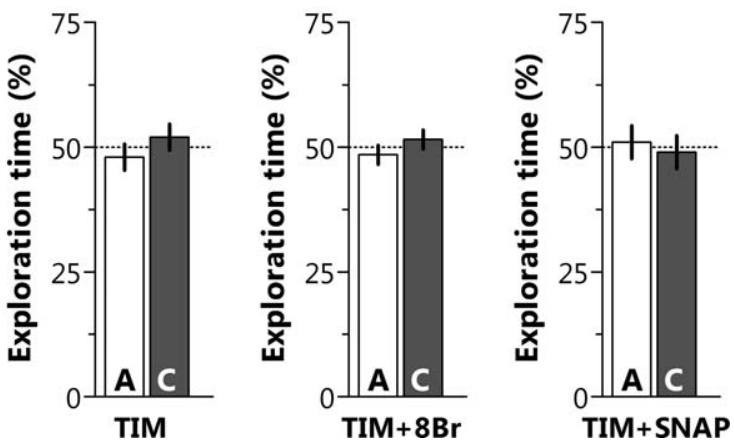

FIGURE 4. The amnesic effect of the posttraining intra-CA administration of the $\beta$-adrenergic antagonist timolol is not reversed by coinfusion of $8 \mathrm{Br}$-cGMP or the NO donor SNAP. On day 1 (training), rats were exposed to two different objects (A and B) for $5 \mathrm{~min}$ and immediately after that received bilateral intraCA1 infusions ( $1 \mu \mathrm{l} /$ side) of vehicle (VEH; $0.1 \%$ DMSO in saline), the $\beta$-adrenergic blocker timolol (TIM; $1 \mu \mathrm{g} / \mathrm{side}$ ), or a combina- tion of TIM plus $8 \mathrm{Br}$-cGMP $(8 \mathrm{Br} ; 5 \mu \mathrm{g} /$ side), or TIM plus SNAP ( $5 \mu \mathrm{g} / \mathrm{side}$ ). On day 2 (test), animals were exposed to a familiar (A) and a novel object (C) for five extra minutes to evaluate longterm memory retention. Data (mean $\pm S E M)$ are presented as percentage of total exploration time. ${ }^{* * *} P<0.001$ in one-sample Student's $t$-test with theoretical mean $=50 ; n=10$ per group. 
Day 1

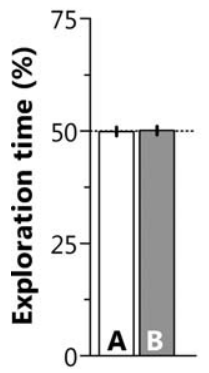

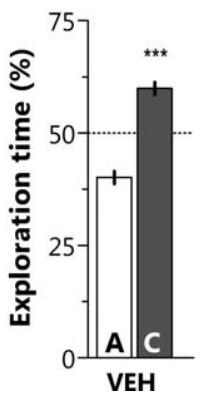

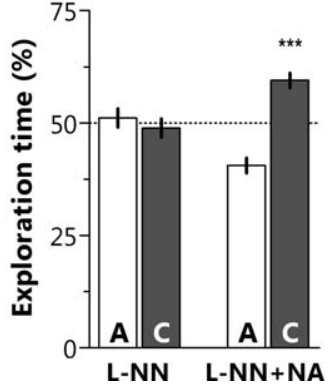

Day 2

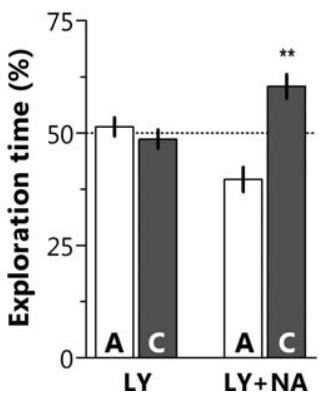

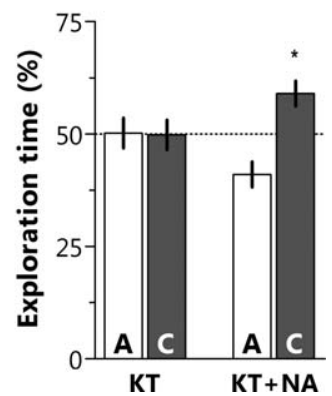

FIGURE 5. Noradrenaline reverses the amnesia induced by the intra-CA1 administration of L-NN, LY83583, and KT5823. On day 1 (training), rats were exposed to two different objects ( $A$ and B) for $5 \mathrm{~min}$ and immediately after that received bilateral intraCA1 infusions ( $1 \mu \mathrm{l} /$ side) of vehicle (VEH; $0.1 \%$ DMSO in saline), L-NN (1 $\mu \mathrm{g} / \mathrm{side}$ ), LY83583 (LY; $200 \mathrm{ng} /$ side), KT5823 (KT; 100 ng/side), or a combination of L-NN, LY, or KT plus noradrenaline

Although the physiological effectors of the NOS/sGC/ cGMP/PKG pathway in the hippocampus have not been entirely elucidated, several reports indicate that stimulation of NA release is an important downstream factor of this signaling cascade. In this respect, it has been shown that inhibition of nNOS prevents the depletion of hippocampal NA induced by the NA-uptake blocker DSP-4 (Szökó et al., 2001) and that different NO donors stimulate NA release in hippocampal slices (Lonart et al., 1992; Satoh et al., 1996, 1997) and potentiate that elicited by 3,4-diaminopyridine (Lauth et al., 1993) and NMDA (Jones et al., 1994, 1995; Stout and Woodward, 1995). When given into dorsal CA1 immediately after training, the $\beta$-adrenergic receptor blocker timolol ( $1 \mu \mathrm{g} /$ side) hampered OR LTM (Fig. 4, TIM). This effect was not prevented by coinfusion of either 8Br-cGMP $(5 \mu \mathrm{g} /$ side; Fig. 4, TIM + $8 \mathrm{Br})$ or the NO-donor SNAP $(5 \mu \mathrm{g} /$ side; Fig. $4 \mathrm{~A}$, TIM + SNAP). However, the amnesia caused by intra-CA1 infusion of L-NN, LY83583, and KT5823 was reversed by coadministration of NA $\left(1 \mu \mathrm{g} / \mathrm{side}\right.$; Fig. 5 ; $t_{(9)}=5.79, P<0.001$ for L-NN/NA; $t_{(9)}=3.84, P<0.01$ for LY83583/NA and $t_{(9)}=$ 3.19, $P<0.05$ for KT5823/NA in one-sample Student's $t$-test with theoretical mean $=50$ ) indicating that stimulation of hippocampal adrenergic receptors is essential for OR LTM consolidation and that this step is downstream the activation of the $\mathrm{NOS} / \mathrm{sGC/cGMP/PKG} \mathrm{signaling} \mathrm{pathway.}$

Recent findings suggest that acting via cGMP- and NA-dependent mechanisms NO increases expression of BDNF (Chen and Russo-Neustadt, 2007), a neurotrophin that plays an essential role in memory formation and persistence (Bekinschtein et al., 2008; Lu et al., 2008). Thus, we studied the possible existence of a causal link between NOS activation, $\beta$-adrenergic receptor stimulation, and BDNF expression during OR memory consolidation. As seen from Figure 6, intra-CA1 infusion of function-blocking anti-BDNF antibodies right after training hindered OR LTM retention (Fig. 6A). Moreover, OR training induced a clear-cut increase in BDNF levels in dorsal CA1 peaking $120 \mathrm{~min}$ posttraining (Fig. 6B; $F_{(3,19)}=4.18, P<$ 0.05; $q=3.49, P<0.05$ in Dunnett's comparison test after
(NA; $1 \mu \mathrm{g} / \mathrm{side}$ ). On day 2 (test), animals were exposed to a familiar (A) and a novel object (C) for five extra minutes to evaluate long-term memory retention. Data (mean \pm SEM) are presented as percentage of total exploration time. ${ }^{* * *} P<0.001$, ${ }^{* *} P<0.01$, and $* P<0.05$ in one-sample Student's $t$-test with theoretical mean $=50 ; n=10$ per group.

ANOVA), which was blocked (Fig. 6C) by L-NN and timolol $\left(F_{(3,14)}=9.12, P<0.01 ; q=3.39, P<0.05\right.$ for $\mathrm{L}-\mathrm{NN}$ and $q=3.95, P<0.01$ for timolol in Dunnett's comparison test after ANOVA) and enhanced by SNAP and NA given into dorsal CA1 immediately after training $\left(F_{(3,14)}=8.01, P<0.01\right.$; $q=3.96, P<0.01$ for NA and $q=2.51, P<0.05$ for SNAP in Dunnett's comparison test after ANOVA). Surprisingly, coinfusion of BDNF, at a dose previously shown to reverse the amnesia induced by protein synthesis inhibitors on fear-memory $(0.25 \mu \mathrm{g} / \mu \mathrm{l}$; Beckinschtein et al., 2007), did not prevent the amnesic effect of the posttraining administration of L-NN and timolol (Fig. 6D).

\section{DISCUSSION}

Our results concur with earlier reports on the activation of the NOS/sGC/PKG pathway during information processing. Indeed, it is known that the inhibition of NOS activity in some brain regions impairs memory in different animal species (Baratti and Kopf, 1996; Myslivecek et al., 1996; Rickard et al., 1998; Xu et al., 2007), while NOS activators and NO donors increase retention (Telegdy and Kokavszky, 1997; Khavandgar et al., 2003; Pitsikas et al., 2005). Similarly, drugs that decrease sGC or PKG activity are generally amnesic whereas those that increase cGMP levels enhance memory (Bernabeu et al., 1996, 1997; Chien et al., 2005). Nonetheless, most studies regarding the role of NO on memory have used aversionmotivated learning tasks and, consequently, very little is known about the participation of this signaling cascade in the consolidation of nonaversive declarative LTM. The present data show that when infused in dorsal CA1, L-NN hindered OR LTM retention. This effect was reversed by coinfusion of the NO-donor SNAP and observed only when L-NN was given immediately but not 180 or 360 min after training, suggesting that the amnesia caused by L-NN was due to blockade of the consolidation process caused by temporary inhibition of hippocampal 
A Day 1

Day 2
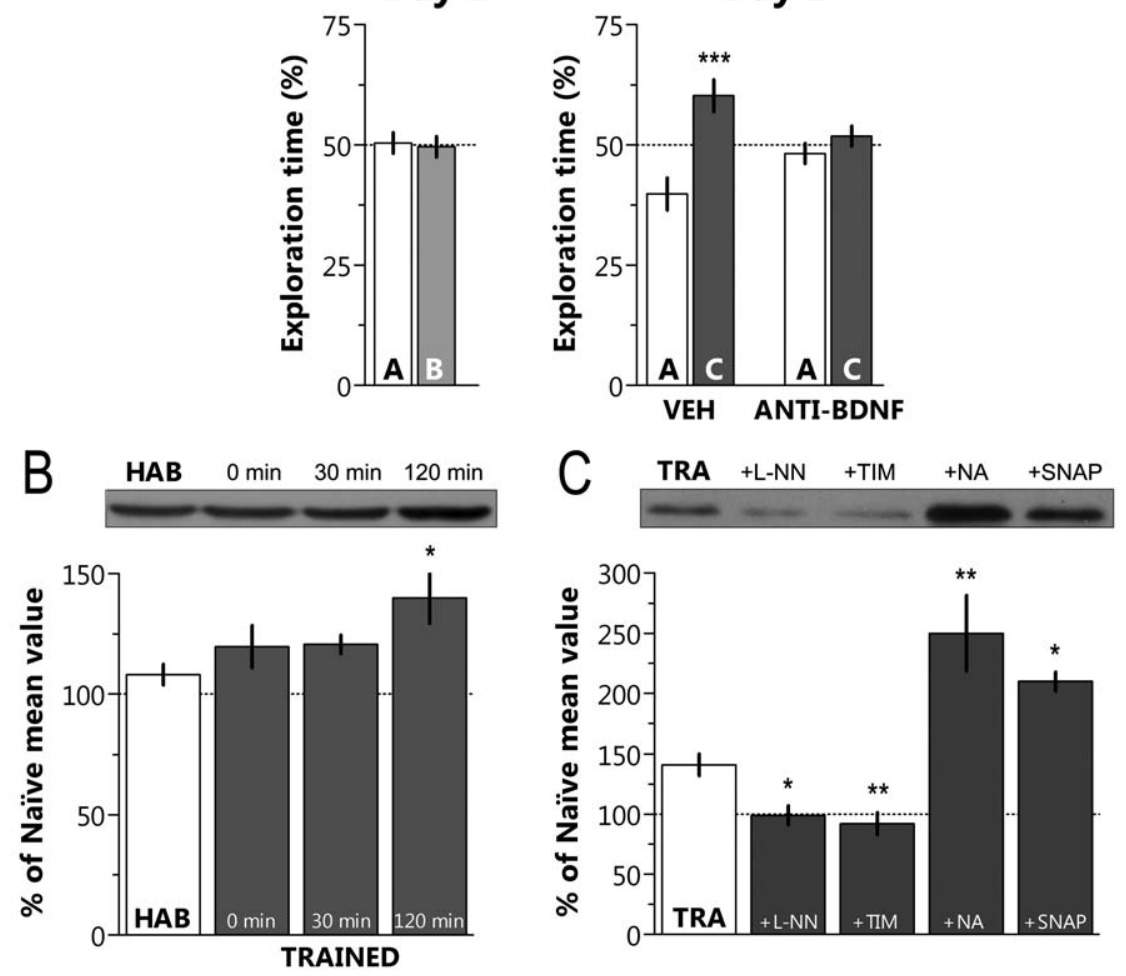

$\mathrm{D}$

Day 1
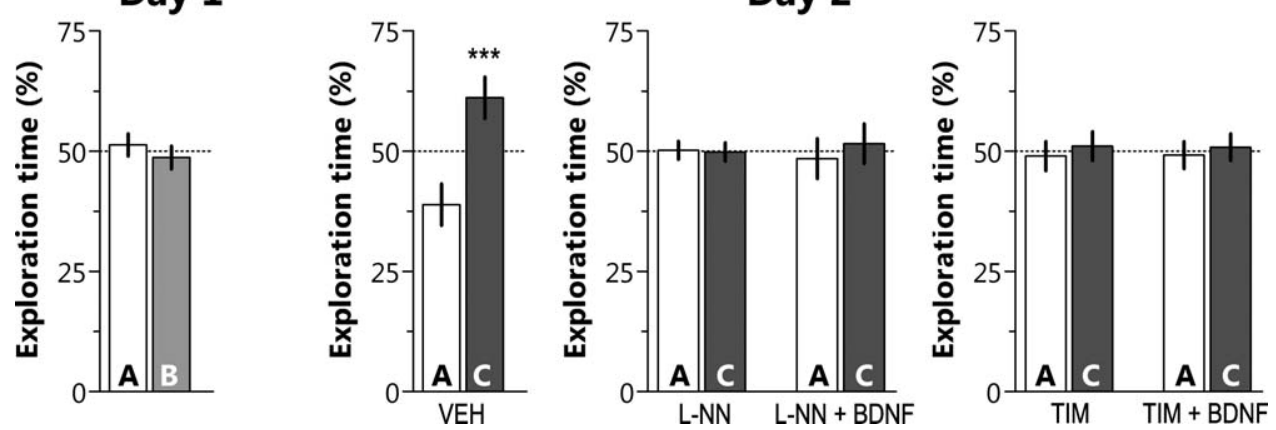

FIGURE 6. Consolidation of OR long-term memory increases BDNF levels in the dorsal CA1 region through a NO- and $\beta$-adrenergic receptor-dependent mechanism. A: On day 1 (training), rats were exposed to two different objects (A and B) for $5 \mathrm{~min}$ and immediately after that received bilateral intra-CA1 infusions $(1 \mu \mathrm{l} /$ side) of vehicle (VEH; $0.1 \%$ DMSO in saline) or function-blocking anti-BDNF antibodies (ANTI-BDNF; $1 \mu \mathrm{g} /$ side). On day 2 (test), animals were exposed to a familiar (A) and a novel object (C) for five extra minutes to evaluate long-term memory retention. Data (mean \pm SEM) are presented as percentage of total exploration time. ${ }^{* * *} P<0.001$ in one-sample Student's $t$-test with theoretical mean $=50 ; n=10$ per group. B: Animals were trained in the OR task (TRAINED) or submitted to a 5-min long free exploration session of the training arena in the absence of stimulus objects (HAB). At different times, after that, the animals were killed by decapitation, the dorsal CA1 region dissected out and total homogenates submitted to SDS-PAGE followed by immunoblot analysis with antibodies against BDNF. As no differences were found among the HAB groups, only the $H A B 120$ min group is shown. Bars show normalized mean percentage levels respect to

naive animals. Data are expressed as mean \pm SEM. ${ }^{*} P<0.05$ in Dunnett's comparison test versus HAB after ANOVA; $n=5$ per group. C: Animals with infusion cannulas aimed to the CA1 region of the dorsal hippocampus were trained in the OR task. Immediately after that the animals received bilateral intra-CA1 infusions $(1 \mu \mathrm{l} /$ side) of vehicle (TRA), L-NN ( $1 \mu \mathrm{g} /$ side), timolol (TIM; $1 \mu \mathrm{g} / \mathrm{side}$ ), noradrenaline (NA; $1 \mu \mathrm{g} /$ side), or SNAP $(5 \mu \mathrm{g} /$ side) and were killed by decapitation $120 \mathrm{~min}$ later. The dorsal CA1 region was dissected out and total homogenates submitted to SDS-PAGE followed by immunoblot analysis with antibodies against BDNF. Bars show normalized mean percentage levels respect to naive animals. Data are expressed as mean $\pm S E M . ~ * P<$ 0.05 and ${ }^{* *} P<0.01$ in Dunnett's comparison test versus TRA after ANOVA; $n=5$ per group. D: Animals were trained and tested as in (A) but instead received bilateral intra-CA1 infusions of vehicle (VEH; 0.1\% DMSO in saline), L-NN ( $1 \mu \mathrm{g} / \mathrm{side})$, timolol (TIM; $1 \mu \mathrm{g} / \mathrm{side}$ ), or a combination of L-NN or TIM plus BDNF $(0.25 \mu \mathrm{g} / \mathrm{side})$. Data (mean $\pm \mathrm{SEM})$ are presented as percentage of total exploration time. ${ }^{* * *} \boldsymbol{P}<0.001$ in one-sample Student's $\boldsymbol{t}$-test with theoretical mean $=50 ; n=10$ per group. 
$\mathrm{nNOS}$ and not to an unspecific or toxic pharmacological effect or to a tardy impairment of behavioral activity. In fact, L-NN did not affect the animals' performance in the elevated plus maze, in the open field or in the inhibitory avoidance test when administered $24 \mathrm{~h}$ before the respective behavioral session. Moreover, pretest infusion of L-NN did not affect OR LTM retrieval nor reversed the amnesia caused by its posttraining administration, indicating that the amnesic effect caused by inhibition of hippocampal nNOS is not due to state-dependent learning. This result is particularly important inasmuch it was previously reported that inhibition of hippocampal NOS induces a state-dependent impairment in OR STM (Blokland et al., 1998). The reasons for this discrepancy are surely related to the fact that Blokland and coworkers used the nonisoform specific NOS inhibitor L-NA instead of the nNOS specific blocker L$\mathrm{NN}$, used a dose 30-times higher than the one we used in our experiments and, most importantly, measured memory retention just $1 \mathrm{~h}$ after training. Therefore, besides dealing with a totally different mnemonic process (i.e., short-term vs. LTM), their experiments were unable to rule out conclusively the occurrence of nonspecific behavioral and physiological effects.

That the $\mathrm{nNOS} / \mathrm{sGC} / \mathrm{PKG}$ pathway in dorsal CA1 plays an essential role during the consolidation of OR LTM was further demonstrated by results showing that: (1) OR training induces a rapid increase in hippocampal NOx content; (2) the sGC inhibitor LY83583 and the PKG inhibitor KT5823 mimicked the amnesic effect of L-NN, whereas the nonhydrolysable ana$\log$ of cGMP $8 \mathrm{Br}$-cGMP reversed the amnesia induced by LNN and LY83583 but not KT5823. These findings, together with others showing that the NO-donor SNAP was unable to reverse the amnesic effect of LY83583 and KT5823, indicate that consolidation of OR LTM is indeed associated with an early increase in NO synthesis, and suggest that the most likely mechanism through which NO brings about the physiological changes involved in this process require the sequential activation of sGC and PKG. Indeed, there is abundant evidence regarding the participation of the NO-mediated activation of sGC/PKG in plasticity (East and Garthwaite, 1991; Chetkovich et al., 1993; Zhuo et al., 1994; Arancio et al., 1995; DomekŁopacińska and Strosznajder, 2008; Wang et al., 2008).

Although the downstream effectors of the NO/sGC/PKG pathway during memory processing are not known, findings indicating that several NO donors (Lonart et al., 1992, 1995; Stout and Woodward, 1994; Satoh et al., 1996) modulate NA release in different brain preparations (Yu and Wecker, 1994; Jones et al., 1995; Chu and Etgen, 1996; Martire et al., 1998), including the hippocampus (Lauth et al., 1995; Kiss et al., 1996; Satoh et al., 1996, 1997), together with a recent report showing that inhibition of NOS and sGC modulates the NAinduced increase in hippocampal BDNF levels (Chen and Russo-Neustadt, 2007), suggest that activation of NA receptors signaling could be an important link between NO generation and learning-induced gene expression. In this respect, our results showing that neither $8 \mathrm{Br}-\mathrm{cGMP}$ nor SNAP reversed the amnesic effect of the intra-CA1 administration of timolol while NA overturned the amnesia caused by the immediate posttraining infusion of L-NN, LY83583 and KT5823 demonstrate that activation of hippocampal $\beta$-adrenergic receptors is essential for consolidation of OR LTM and support the hypothesis that these receptors act downstream the $\mathrm{NO} / \mathrm{sGC} /$ PKG pathway. Moreover, the fact that L-NN and timolol hamper, while NA and SNAP enhance, the learning-induced increase in hippocampal BDNF levels, strongly suggests that $\beta$ adrenergic receptors link $\mathrm{NO} / \mathrm{sGC} / \mathrm{PKG}$ signaling to BDNF expression during the consolidation of OR LTM (Fig. 7). These results are in agreement with previous reports suggesting that the beneficial cognitive effect of different behavioral therapies, including moderate voluntary physical exercise, are mediated by a NO- and noradrenergic-controlled increase in hippocampal BDNF expression (Garcia et al., 2003; Chen et al., 2006; Ma, 2008). However, the fact that posttraining intraCA1 administration of BDNF did not reverse the amnesic effect of L-NN and timolol suggest that, although controlled by NO and NA and necessary for consolidation, the expression of this neurotrophin is not sufficient for the establishment of a stable and long-lasting recognition memory trace. This observation is important because it has been proposed that some mem-

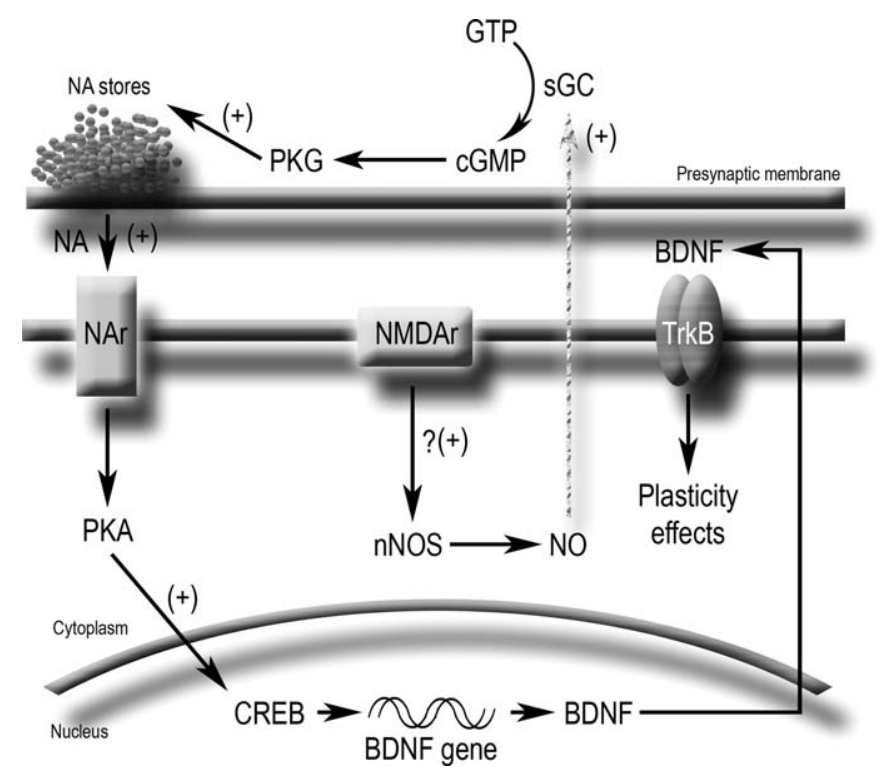

FIGURE 7. Hypothetic diagram illustrating the putative events mediating the involvement of the NO/sGC/PKG cascade in OR memory consolidation. An unknown receptor, probably the NMDA receptor (Frade et al., 2008), activates nNOS early after training, rapidly increasing NO levels in the postsynaptic terminal. NO diffuses to the presynaptic compartment (Hawkins et al., 1999) where it induces the activation of sGC and the consequent increase in cGMP and PKG activity (Wang et al., 2005). PKG, in turn, promotes the release of different neurotransmitters, including noradrenaline (NE) (Wang and Robinson, 1997; Yawo et al., 1999) which acting on $\beta$-adrenergic receptors induces the expression of BDNF (Chen et al., 2007), maybe through a pathway involving the activation of PKA and CREB. BDNF is then secreted and binds its receptor TrkB in an autocrine or paracrine manner to promote some of the plastic modifications in synaptic efficacy required for the lasting stabilization of the mnemonic trace (Lu et al., 2008). 
ory impairments associated with normal aging and $\mathrm{AD}$ could be counterbalanced by administration of exogenous BDNF and/or by stimulating its expression (Tapia-Arancibia et al., 2008).

\section{REFERENCES}

Arancio O, Kandel ER, Hawkins RD. 1995. Activity-dependent long-term enhancement of transmitter release by presynaptic 3',5'-cyclic GMP in cultured hippocampal neurons. Nature 376: 74-80.

Arnold WP, Mittal CK, Katsuki S, Murad F. 1977. Nitric oxide activates guanylate cyclase and increases guanosine $3^{\prime}: 5^{\prime}$-cyclic monophosphate levels in various tissue preparations. Proc Natl Acad Sci USA 74:3203-3207.

Balderas I, Rodriguez-Ortiz CJ, Salgado-Tonda P, Chavez-Hurtado J, McGaugh JL, Bermudez-Rattoni F. 2008. The consolidation of object and context recognition memory involve different regions of the temporal lobe. Learn Mem 15:618-624.

Baratti CM, Kopf SR. 1996. The post-training memory enhancement induced by physostigmine and oxotremorine in mice is not statedependent. Neurobiol Learn Mem 65:121-124.

Bekinschtein P, Cammarota M, Igaz LM, Bevilaqua LR, Izquierdo I, Medina JH. 2007. Persistence of long-term memory storage requires a late protein synthesis- and BDNF- dependent phase in the hippocampus. Neuron 53:261-277.

Bekinschtein P, Cammarota M, Katche C, Slipczuk L, Rossato JI, Goldin A, Izquierdo I, Medina JH. 2008. BDNF is essential to promote persistence of long-term memory storage. Proc Natl Acad Sci USA 105:2711-2716.

Bernabeu R, Schmitz P, Faillace MP, Izquierdo I, Medina JH. 1996. Hippocampal cGMP and cAMP are differentially involved in memory processing of inhibitory avoidance learning. Neuroreport 7:585-588.

Bernabeu R, Schroder N, Quevedo J, Cammarota M, Izquierdo I, Medina JH. 1997. Further evidence for the involvement of a hippocampal cGMP-dependent protein kinase cascade in memory consolidation. Neuroreport 8:2221-2224.

Bevilaqua LR, Medina JH, Izquierdo I, Cammarota M. 2005. Memory consolidation induces $N$-methyl-D-aspartic acid-receptor- and $\mathrm{Ca}^{2+}$ /calmodulin-dependent protein kinase II-dependent modifications in alpha-amino-3-hydroxy-5-methylisoxazole-4-propionic acid receptor properties. Neuroscience 136:397-403.

Blokland A, Prickaerts J, Honig W, De Vente J. 1998. State-dependent impairment in object recognition after hippocampal NOS inhibition. Neuroreport 9:4205-4208.

Bouallegue A, Daou GB, Srivastava AK. 2007. Nitric oxide attenuates endothelin-1-induced activation of ERK1/2, PKB, and Pyk2 in vascular smooth muscle cells by a cGMP-dependent pathway. Am J Physiol Heart Circ Physiol 293:H2072-H2079.

Boulton CL, Southam E, Garthwaite J. 1995. Nitric oxide-dependent long-term potentiation is blocked by a specific inhibitor of soluble guanylyl cyclase. Neuroscience 69:699-703.

Budson AE, Dodson CS, Daffner KR, Schacter DL. 2005. Metacognition and false recognition in Alzheimer's disease: Further exploration of the distinctiveness heuristic. Neuropsychology 19:253-258.

Cammarota M, Bevilaqua LR, Rossato JI, Lima RH, Medina JH, Izquierdo I. 2008. Parallel memory processing by the CA1 region of the dorsal hippocampus and the basolateral amygdala. Proc Natl Acad Sci USA 105:10279-10284.

Chabrier PE, Demerlé-Pallardy C, Auguet M. 1999. Nitric oxide synthases: Targets for therapeutic strategies in neurological diseases. Cell Mol Life Sci 55:1029-1035.
Chen MJ, Russo-Neustadt AA. 2007. Nitric oxide signaling participates in norepinephrine-induced activity of neuronal intracellular survival pathways. Life Sci 81:1280-1290.

Chen MJ, Ivy AS, Russo-Neustadt AA. 2006. Nitric oxide synthesis is required for exercise-induced increases in hippocampal BDNF and phosphatidylinositol 3' kinase expression. Brain Res Bull 68:257268.

Chetkovich DM, Klann E, Sweatt JD. 1993. Nitric oxide synthase-independent long-term potentiation in area CA1 of hippocampus. Neuroreport 4:919-922.

Chien WL, Liang KC, Teng CM, Kuo SC, Lee FY, Fu WM. 2003. Enhancement of long-term potentiation by a potent nitric oxideguanylyl cyclase activator, 3-(5-hydroxymethyl-2-furyl)-1-benzyl-indazole. Mol Pharmacol 63:1322-1328.

Chien WL, Liang KC, Teng CM, Kuo SC, Lee FY, Fu WM. 2005. Enhancement of learning behaviour by a potent nitric oxide-guanylate cyclase activator YC-1. Eur J Neurosci 21:1679-1688.

Chu HP, Etgen AM. 1996. Effects of nitric oxide on stimulated release of norepinephrine from female rat hypothalamic slices. Brain Res 741:60-67.

Clark RE, Zola SM, Squire LR. 2000. Impaired recognition memory in rats after damage to the hippocampus. J Neurosci 20:88538860 .

Domek-Łopacińska K, Strosznajder JB. 2008. The effect of selective inhibition of cyclic GMP hydrolyzing phosphodiesterases 2 and 5 on learning and memory processes and nitric oxide synthase activity in brain during aging. Brain Res 1216:68-77.

Dudas RB, Clague F, Thompson SA, Graham KS, Hodges JR. 2005. Episodic and semantic memory in mild cognitive impairment. Neuropsychologia 43:1266-1276.

East SJ, Garthwaite J. 1991. NMDA receptor activation in rat hippocampus induces cyclic GMP formation through the L-arginine-nitric oxide pathway. Neurosci Lett 123:17-19.

Edwards TM, Rickard NS. 2007. New perspectives on the mechanisms through which nitric oxide may affect learning and memory processes. Neurosci Biobehav 31:413-425.

Ennaceur A, Delacour J. 1988. A new one-trial test for neurobiological studies of memory in rats. I. Behavioral data. Behav Brain Res 31:47-59.

Frade JG, Barbosa RM, Laranjinha J. 2009. Stimulation of NMDA and AMPA glutamate receptors elicits distinct concentration dynamics of nitric oxide in rat hippocampal slices. Hippocampus [Epub ahead of print]

Garcia C, Chen MJ, Garza AA, Cotman CW, Russo-Neustadt A. 2003. The influence of specific noradrenergic and serotonergic lesions on the expression of hippocampal brain-derived neurotrophic factor transcripts following voluntary physical activity. Neuroscience 119:721-732.

Gliebus G, Lippa CF. 2007. The influence of beta-blockers on delayed memory function in people with cognitive impairment. Am J Alzheimers Dis Other Demen 22:57-61.

Grandati M, Verrecchia C, Revaud ML, Allix M, Boulu RG, Plotkine M. 1997. Calcium-independent NO-synthase activity and nitrites/ nitrates production in transient focal cerebral ischaemia in mice. $\mathrm{Br}$ J Pharmacol 122:625-630.

Haenisch B, Gilsbach R, Bönisch H. 2008. Neurotrophin and neuropeptide expression in mouse brain is regulated by knockout of the norepinephrine transporter. J Neural Transm 15:973-982.

Haghikia A, Mergia E, Friebe A, Eysel UT, Koesling D, Mittmann T. 2007. Long-term potentiation in the visual cortex requires both nitric oxide receptor guanylyl cyclases. J Neurosci 27:818-823.

Haglund M, Sjöbeck M, Englund E. 2006. Locus ceruleus degeneration is ubiquitous in Alzheimer's disease: Possible implications for diagnosis and treatment. Neuropathology 26:528-532.

Hanbauer I, Wink D, Osawa Y, Edelman GM, Gally JA. 1992. Role of nitric oxide in NMDA-evoked release of [3H]-dopamine from striatal slices. Neuroreport 3:409-412. 
Hawkins RD, Kandel ER, Siegelbaum SA. 1993. Learning to modulate transmitter release: Themes and variations in synaptic plasticity. Annu Rev Neurosci 16:625-665.

Hawkins RD, Son H, Arancio O. 1998. Nitric oxide as a retrograde messenger during long-term potentiation in hippocampus. Prog Brain Res 118:155-172.

Hutter P, Johansson M, Saria A, Humpel C. 1996. Acute and chronic noradrenergic regulation of neurotrophin messenger RNA expression in rat hippocampus: Evidence from lesions and organotypic cultures. Neuroscience 70:15-29.

Ihalainen JA, Riekkinen PJR, Feenstra MG. 1999. Comparison of dopamine and noradrenaline release in mouse prefrontal cortex, striatum and hippocampus using microdialysis. Neurosci Lett 277:7174.

Izquierdo I, Bevilaqua LR, Rossato JI, Bonini JS, Medina JH, Cammarota M. 2006. Different molecular cascades in different sites of the brain control memory consolidation. Trends Neurosci 29:496-505.

Jones NM, Loiacono RE, Møller M, Beart PM. 1994. Diverse roles for nitric oxide in synaptic signalling after activation of NMDA release-regulating receptors. Neuropharmacology 33:1351-1356.

Jones NM, Loiacono RE, Beart PM. 1995. Roles for nitric oxide as an intra- and interneuronal messenger at NMDA release-regulating receptors: Evidence from studies of the NMDA-evoked release of $[3 \mathrm{H}]$ noradrenaline and $\mathrm{D}-[3 \mathrm{H}]$ aspartate from rat hippocampal slices. J Neurochem 64:2057-2063.

Jouvert P, Revel MO, Lazaris A, Aunis D, Langley K, Zwiller J. 2004. Activation of the cGMP pathway in dopaminergic structures reduces cocaine-induced EGR-1 expression and locomotor activity. J Neurosci 24:10716-10725.

Khavandgar S, Homayoun H, Zarrindast MR. 2003. The effect of LNAME and L-arginine on impairment of memory formation and state-dependent learning induced by morphine in mice. Psychopharmacology 167:291-296.

Kiss JP, Sershen H, Lajtha A, Vizi ES. 1996. Inhibition of neuronal nitric oxide synthase potentiates the dimethylphenylpiperaziniumevoked carrier-mediated release of noradrenaline from rat hippocampal slices. Neurosci Lett 215:115-118.

Kobayashi K, Yasoshima Y. 2001. The central noradrenaline system and memory consolidation. Neuroscientist 7:371-376.

Laatu S, Revonsuo A, Jäykkä H, Portin R, Rinne JO. 2003. Visual object recognition in early Alzheimer's disease: Deficits in semantic processing. Acta Neurol Scand 108:82-89.

Lahiri DK, Chen D, Ge YW, Farlow M, Kotwal G, Kanthasamy A, Ingram DK, Greig NH. 2003. Does nitric oxide synthase contribute to the pathogenesis of Alzheimer's disease? Effects of $\beta$-amyloid deposition on NOS in transgenic mouse brain with AD pathology. Ann NY Acad Sci 1010:639-642.

Lauth D, Hertting G, Jackisch R. 1993. Involvement of nitric oxide synthase in 3,4-diaminopyridine-evoked noradrenaline release in rat hippocampus. Eur J Pharmacol 236:165-166.

Lauth D, Hertting G, Jackisch R. 1995. 3,4-Diaminopyridine-evoked noradrenaline release in rat hippocampal slices: Facilitation by endogenous or exogenous nitric oxide. Brain Res 692:174-182.

Lee AC, Rahman S, Hodges JR, Sahakian BJ, Graham KS. 2003. Associative and recognition memory for novel objects in dementia: Implications for diagnosis. Eur J Neurosci 18:1660-1670.

Logothetis NK, Sheinberg DL. 1996. Visual object recognition. Ann Rev Neurosci 19:577-621.

Lonart G, Johnson KM. 1995. Characterization of nitric oxide generator-induced hippocampal $[3 \mathrm{H}]$ norepinephrine release. I. The role of glutamate. J Pharmacol Exp Ther 275:7-13.

Lonart G, Wang J, Johnson KM. 1992. Nitric oxide induces neurotransmitter release from hippocampal slices. Eur J Pharmacol 220:271-272.

Lu YF, Kandel ER, Hawkins RD. 1999. Nitric oxide signaling contributes to late-phase LTP, CREB phosphorylation in the hippocampus. J Neurosci 19:10250-10261.
Lu Y, Christian K, Lu B. 2008. BDNF: A key regulator for protein synthesis-dependent LTP, long-term memory? Neurobiol Learn Mem 89:312-323.

Lüth HJ, Ogunlade V, Kuhla B, Kientsch-Engel R, Stahl P, Webster J, Arendt T, Münch G. 2005. Age- and stage-dependent accumulation of advanced glycation end products in intracellular deposits in normal and Alzheimer's disease brains. Cereb Cortex 15:211-220.

Ma Q. 2008. Beneficial effects of moderate voluntary physical exercise and its biological mechanisms on brain health. Neurosci Bull 24:265-270.

Malinski T. 2007. Nitric oxide and nitroxidative stress in Alzheimer's disease. J Alzheimers Dis 11:207-218.

Martire M, Altobelli D, Cannizzaro C, Preziosi P. 1998. Effects of nitric oxide donors on basal and $\mathrm{K}+$-evoked release of $[3 \mathrm{H}]$ noradrenaline from rat cerebral cortex synaptosomes. Eur J Pharmacol 350:345-351.

Myskiw JC, Rossato JI, Bevilaqua LR, Medina JH, Izquierdo I, Cammarota M. 2008. On the participation of $m$ TOR in recognition memory. Neurobiol Learn Mem 89:338-351.

Myslivecek J, Hassmannová J, Barcal J, Safanda J, Zalud V. 1996. Inhibitory learning and memory in newborn rats influenced by nitric oxide. Neuroscience 71:299-312.

Ota KT, Pierre VJ, Ploski JE, Queen K, Schafe GE. 2008. The NO-cGMP-PKG signaling pathway regulates synaptic plasticity and fear memory consolidation in the lateral amygdala via activation of ERK/MAP kinase. Learn Mem 15:792-805.

Paxinos G, Watson C. 1986. The Rat Brain in Stereotaxic Coordinates. San Diego, CA: Academic Press. 119 p.

Pellow S, Chopin P, File SE, Briley M. 1985. Validation of open:closed arm entries in an elevated plus-maze as a measure of anxiety in the rat. J Neurosci Methods 14:149-167.

Pitsikas N, Rigamonti AE, Cella SG, Muller EE. 2002. Effects of the nitric oxide donor molsidomine on different memory components as assessed in the object-recognition task in the rat. Psychopharmacology 162:239-245.

Pitsikas N, Rigamonti AE, Cella SG, Sakellaridis N, Muller EE. 2005. The nitric oxide donor molsidomine antagonizes age-related memory deficits in the rat. Neurobiol Aging 26:259-264.

Prickaerts J, Steinbusch HW, Smits JF, De Vente J. 1997. Possible role of nitric oxide-cyclic GMP pathway in object recognition memory: Effects of 7-nitroindazole and zaprinast. Eur J Pharmacol 337:125-136.

Prieto-Castelló MJ, Hernández-Viadel ML, Cardona A, Marhuenda D, Felipo V. 2007. Activation of soluble guanylate cyclase by nitric oxide is increased in lymphocytes from both rats chronically exposed to 2,5-hexanedione and workers chronically exposed to n-hexane. Toxicology 229:73-78.

Rickard NS, Ng KT, Gibbs ME. 1998. Further support for nitric oxide-dependent memory processing in the day-old chick. Neurobiol Learn Mem 69:79-86.

Riesenhuber M, Poggio T. 2002. Neural mechanisms of object recognition. Curr Opin Neurobiol 12:16216-16218.

Rodrigo J, Fernández-Vizarra P, Castro-Blanco S, Bentura ML, Nieto M, Gómez-Isla T, Martínez-Murillo R, MartInez A, Serrano J, Fernández AP. 2004. Nitric oxide in the cerebral cortex of amyloid-precursor protein (SW) Tg2576 transgenic mice. Neuroscience 128:73-89.

Romieu P, Gobaille S, Aunis D, Zwiller J. 2008. Injection of the neuropeptide CNP into dopaminergic rat brain areas decreases alcohol intake. Ann NY Acad Sci 1139:27-33.

Roozendaal B, Castello NA, Vedana G, Barsegyan A, Mcgaugh JL. 2008. Noradrenergic activation of the basolateral amygdala modulates consolidation of object recognition memory. Neurobiol Learn Mem 90:576-579.

Rossato JI, Bevilaqua RM, Myskiw JC, Medina JH, Izquierdo I, Cammarota M. 2007. On the role of hippocampal protein synthesis in the consolidation and reconsolidation of object recognition memory. Learn Mem 14:36-46. 
Satoh S, Kimura T, Toda M, Miyazaki H, Ono S, Narita H, Murayama T, Nomura Y. 1996. NO donors stimulate noradrenaline release from rat hippocampus in a calmodulin-dependent manner in the presence of L-cysteine. J Physiol 169:87-96.

Satoh S, Kimura T, Toda M, Maekawa M, Ono S, Narita H, Miyazaki H, Murayama T, Nomura Y. 1997. Involvement of L-type-like amino acid transporters in $S$-nitrosocysteine-stimulated noradrenaline release in the rat hippocampus. J Neurochem 69:2197-2205.

Shin JH, Linden DJ. 2005. An NMDA receptor/nitric oxide cascade is involved in cerebellar LTD but is not localized to the parallel fiber terminal. J Neurophysiol 94:4281-4289.

Son H, Hawkins RD, Martin K, Kiebler M, Huang PL, Fishman MC, Kandel ER. 1996. Long-term potentiation is reduced in mice that are doubly mutant in endothelial and neuronal nitric oxide synthase. Cell 87:1015-1023.

Spolidório PC, Echeverry MB, Iyomasa M, Guimarães FS, Del Bel EA. 2007. Anxiolytic effects induced by inhibition of the nitric oxide-cGMP pathway in the rat dorsal hippocampus. Psychopharmacology 195:183-192.

Stepanichev MY, Onufriev MV, Yakovlev AA, Khrenov AI, Peregud DI, Vorontsova ON, Lazareva NA, Gulyaeva NV. 2008. Amyloid$\beta(25-35)$ increases activity of neuronal NO-synthase in rat brain. Neurochem Int 52:1114-1124.

Stout AK, Woodward JJ. 1994. Differential effects of nitric oxide gas and nitric oxide donors on depolarization-induced release of $[3 \mathrm{H}]$ norepinephrine from rat hippocampal slices. Neuropharmacology 33:1367-1374.

Stout AK, Woodward JJ. 1995. Mechanism for nitric oxide's enhancement of NMDA-stimulated [3H]norepinephrine release from rat hippocampal slices. Neuropharmacology 34:723-729.

Szökô E, Haberle D, Halász AS, Tekes K, Magyar K. 2001. Protective effect of 7-nitroindazole against DSP-4 induced noradrenaline depletion in mouse hippocampus. J Neural Transm 108:407-413.

Tapia-Arancibia L, Aliaga E, Silhol M, Arancibia S. 2008. New insights into brain BDNF function in normal aging and Alzheimer disease. Brain Res Rev 59:201-220.

Telegdy G, Kokavszky R. 1997. The role of nitric oxide in passive avoidance learning. Neuropharmacology 36:1583-1587.

Tracey WR, Tse J, Carter G. 1995. Lipopolysaccharide-induced changes in plasma nitrite and nitrate concentrations in rats and mice: Pharmacological evaluation of nitric oxide synthase inhibitors. J Pharmacol Exp Ther 272:1011-1015.

Wang X, Robinson PJ. 1997. Cyclic GMP-dependent protein kinase and cellular signaling in the nervous system. J Neurochem 68:443456.

Wang X, Bruderer S, Rafi Z, Xue J, Milburn PJ, Krämer A, Robinson PJ. 1999. Phosphorylation of splicing factor SF1 on Ser20 by cGMP-dependent protein kinase regulates spliceosome assembly. EMBO J 18:549-559.

Wang HG, Lu FM, Jin I, Udo H, Kandel ER, de Vente J, Walter U, Lohmann SM, Hawkins RD, Antonova I. 2005. Presynaptic and postsynaptic roles of NO, cGK, and RhoA in long-lasting potentiation and aggregation of synaptic proteins. Neuron 45:389-403.

Wang Z, Pan Y, Li W, Jiang H, Chatzimanolis L, Chang J, Gong Z, Liu L. 2008. Visual pattern memory requires foraging function in the central complex of Drosophila. Learn Mem 15:133-142.

Watts J, Fowler L, Whitton PS, Pearce B. 2005. Release of arginine, glutamate and glutamine in the hippocampus of freely moving rats: Involvement of nitric oxide. Brain Res Bull 65:521-528.

Weinshenker D. 2008. Functional consequences of locus coeruleus degeneration in Alzheimer's disease. Curr Alzheimer Res 5:342-345.

Winters BD, Saksida LM, Bussey TJ. 2008. Object recognition memory: Neurobiological mechanisms of encoding, consolidation and retrieval. Neurosci Biobehav Rev 32:1055-1070.

Xu X, Scott-Scheiern T, Kempker L, Simons K. 2007. Active avoidance conditioning in zebrafish (Danio rerio). Neurobiol Learn Mem 87:72-77.

Yawo H. 1999. Involvement of cGMP-dependent protein kinase in adrenergic potentiation of transmitter release from the calyx-type presynaptic terminal. J Neurosci 19:5293-5300.

Yu ZJ, Wecker L. 1994. Chronic nicotine administration differentially affects neurotransmitter release from rat striatal slices. J Neurochem 63:186-194.

Zhang XC, Zhang YQ, Zhao ZQ. 2006. Different roles of two nitric oxide activated pathways in spinal long-term potentiation of Cfiber-evoked field potentials. Neuropharmacology 50:748-754.

Zhuo M, Kandel ER, Hawkins RD. 1994. Nitric oxide and cGMP can produce either synaptic depression or potentiation depending on the frequency of presynaptic stimulation in the hippocampus. Neuroreport 5:1033-1036. 